\title{
The Study of the Composition of Chloroform Fraction of Anemone nemorosa $\mathbf{L}$.
}

\author{
Oksana Khropot $^{\mathrm{a}}$, Yulian Konechnyi ${ }^{\mathrm{b}}$, Nataliya Polish ${ }^{\mathrm{a}}$, Roksolana Konechna ${ }^{\mathrm{a}}$, Yehor Bazavluk ${ }^{\mathrm{a}}$, \\ Olena Korniychuk ${ }^{\mathrm{b}}$, Volodymyr Novikov ${ }^{\mathrm{a}}$ \\ a Department of Technology of Biologically Active Substances, Pharmacy and Biotechnology, \\ Lviv Polytechnic National University, Stepan Bandera Street, 12, Lviv 79013, Ukraine \\ ${ }^{\mathrm{b}}$ Department of Microbiology, Danylo Halytsky Lviv National Medical University, Pekarska Street, \\ 69, Lviv 79010, Ukraine
}

\section{yulian.konechnyi@gmail.com}

Keywords: Anemone nemorosa, chloroform fraction, gas chromatography, lipophilic extract, antimicrobial activity.

Expanding the range of herbal drugs is among the priorities of the modern pharmacy. The analysis presented in this article is drawn from a broader qualitative study examining the composition of Anemone nemorosa L. chloroform fraction. The study revealed 38 compounds, and 32 of them were identified. The investigated lipophilic extract has an antimicrobial activity both in terms of grampositive and gram-negative microorganisms. The maximal antimicrobial action of the investigated extract was shown to Escherichia coli. The significant content of biologically active substances in the lipophilic volatile fraction of Anemone nemorosa indicates the prospects for further study.

\section{Introduction}

In recent years, there has been observed an increasing interest in medicinal herbs [1]. This indicates a need to understand the various aspects of making and producing new phyto-remedies and introducing them into practical use. Anemone nemorosa L. is a herbaceous perennial plant of the buttercup Ranunculaceae family [24]. The plant is considered unofficinal, though it is widely used in folk medicine as an antitumor, sedative, bactericidal, antimicrobial, antifungal, anti-inflammatory, spasmolytic diaphoretic, expectorant, and diuretic drug [5-11]. The major biologically active substances in Anemone nemorosa are: alkaloids, glycosides (proto- anemonin, anemonin, ranunculin, some types of saponins, tannins), vitamin $\mathrm{C}$, resins, organic acids (chelidonic acid), coumarins, flavonoids, and $\gamma$-Linolenic acid [12-15].

Evidence suggests that this herb is referred to as a regionally rare plant of administrative territories of Ukraine [16-17]. Taking into account the wide experience of its use in folk medicine [18], a wide spectrum of pharmacological activity, the content of valuable biologically active compounds [7], as well as the results of phytochemical and pharmacological studies, it becomes clear that the further use of Anemone nemorosa as a valuable medicinal plant material is an urgent task of pharmacy and 
pharmaceutical biotechnology in view of the prospects of scientific research on development and introduction into production of new phytoremedies.

At present, we carry out a systematic study of lipophilic compounds. The main objective of this study is to investigate and determine the component composition of the chloroform fraction of Anemone nemorosa and study of its antimicrobial properties.

\section{Experimental part}

\section{Material and methods}

The object of the study was herb of Anemone nemorosa L. that was collected in 2018 in an ecologically clean region of the Carpathians (Ivano-Frankivsk region, Ukraine), and the lipophilic extract of Anemone nemorosa L. The shade-dried aerial parts were powdered and extracted with the chloroform using a Soxhlet extractor, then the solvent was removed in vacuo until dry extract.

Analysis of biologically active substances of the lipophilic fraction was performed using chromatograph Agilent Technology 6890 GC System with mass spectrometry detector HP 5973 Mass Selective Detector. The components were separated in a fused silica column Restek Rtx-5MS being $30 \mathrm{~m}$ long and having an internal diameter of $0.32 \mathrm{~mm}$. The stationary liquid phase was $0.25 \mu \mathrm{m}$ thick and consisted of $95 \%$ of polymethylsiloxane and $5 \%$ of phenylpolysiloxane. The carrier gas was helium. The velocity of the carrier gas was
$2.0 \mathrm{ml} / \mathrm{min}$. The thermostat of the column was heated in such a program: the initial temperature of $60^{\circ} \mathrm{C}$ was maintained for 10 minutes, and then the temperature was increased with the tempo of $20^{\circ} \mathrm{C} / \mathrm{min}$ to $280^{\circ} \mathrm{C}$. This temperature remained constant for $30 \mathrm{~min}$, the temperature of the detector and the evaporator was $280^{\circ} \mathrm{C}$. Biologically active substances were identified by their retention time, comparing it with standards and with the library of mass spectra NIST 05 and WILEY 2007, the total number of spectra being more than 470000 .

\section{Antibacterial and antifungal bioassay}

Four Gram-negative bacteria (reference strains Pseudomonas aeruginosa (ATCC 27853 (F-51)), Escherichia coli (ATCC 25922) and clinical multi-drug resistance (MDR, according to [19]) strains Pseudomonas aeruginosa, Escherichia coli), five Gram-positive bacteria (reference strains Staphylococcus aureus (ATCC 25923 (F-49)), Staphylococcus epidermidis (191), Bacillus licheniformis (VKPM-7038) and clinical MDR strains Staphylococcus aureus and methicillin-resistant Staphylococcus aureus (MRSA)), and four strain of yeast (reference strains Candida albicans (ATCC 885-653), Candida albicans (ATCC 668-853) and clinical MDR strain Candidadubliniensis and Candida albicans resistant to nistatin sensitive to itraconazole and fluconazole) were used for antibacterial and antifungul activity (disc diffusion and serial dilutions assay). 
Table 1. Antibacterial and antifungul activity of chloroform fraction of Anemone nemorosa L.

\begin{tabular}{|c|c|c|c|c|c|c|c|c|c|c|}
\hline \multirow[t]{2}{*}{ № } & \multirow{2}{*}{\multicolumn{2}{|c|}{ Tipe of species }} & \multirow[t]{2}{*}{ Species of bacteria and fungi } & \multicolumn{5}{|c|}{ Diameter of inhibitory zones $(\mathrm{mm} \pm \mathrm{SD})$} & \multicolumn{2}{|c|}{$\begin{array}{c}\text { Minimum } \\
\text { Inhibitory (MIC) and } \\
\text { Bactericidal /Fungicidal } \\
\text { Concentration (MBC/MFC) }\end{array}$} \\
\hline & & & & $\begin{array}{l}\text { Extract of } \\
\text { Anemone } \\
\text { nemorosa }\end{array}$ & DMSO & Water & $\begin{array}{l}\text { Ampicilin } \\
\text { (10 mcg) }\end{array}$ & $\begin{array}{l}\text { Itraconazole } \\
\quad(10 \mathrm{mcg})\end{array}$ & $\begin{array}{c}\mathrm{MIC} \\
(\mu \mathrm{g} / \mathrm{mL})\end{array}$ & $\begin{array}{c}\mathrm{MBC} / \mathrm{MFC} \\
(\mu \mathrm{g} / \mathrm{mL})\end{array}$ \\
\hline 1 & \multirow{4}{*}{$\begin{array}{l}\text { Gram- } \\
\text { negative } \\
\text { bacteria }\end{array}$} & \multirow[t]{2}{*}{$\begin{array}{c}\text { reference } \\
\text { strains }\end{array}$} & $\begin{array}{l}\text { Pseudomonas aeruginosa } \\
\text { (ATCC } 27853(\mathrm{~F}-51))\end{array}$ & $7.2 \pm 0.3$ & $6.8 \pm 0.2$ & NA & NA & NA & NT & NT \\
\hline 2 & & & $\begin{array}{c}\text { Escherichia coli } \\
\text { (ATCC 25922) }\end{array}$ & $14.2 \pm 0.4$ & $8.0 \pm 0.4$ & NA & $15.2 \pm 0.4$ & NA & 250 & 500 \\
\hline 3 & & \multirow{2}{*}{$\begin{array}{l}\text { clinical } \\
\text { strains }\end{array}$} & Pseudomonas aeruginosa $(\mathrm{n}=4)$ & NA & NA & NA & NA & NA & NT & NT \\
\hline 4 & & & Escherichia coli $(\mathrm{n}=4)$ & NA & $6.4 \pm 0.2$ & NA & $7.4 \pm 0.2$ & NA & NT & NT \\
\hline 5 & \multirow{5}{*}{$\begin{array}{l}\text { Gram- } \\
\text { positive } \\
\text { bacteria }\end{array}$} & \multirow[t]{3}{*}{$\begin{array}{c}\text { reference } \\
\text { strains }\end{array}$} & $\begin{array}{l}\text { Staphylococcus aureus } \\
\text { (ATCC } 25923(\mathrm{~F}-49))\end{array}$ & $10.2 \pm 0.8$ & $7.3 \pm 0.3$ & NA & $18.2 \pm 0.8$ & NA & NT & NT \\
\hline 6 & & & $\begin{array}{c}\text { Staphylococcus epidermidis } \\
(191)\end{array}$ & $9.4 \pm 0.6$ & $7.4 \pm 0.2$ & NA & $19.4 \pm 0.5$ & NA & 250 & 500 \\
\hline 7 & & & $\begin{array}{c}\text { Bacillus licheniformis } \\
(\text { BКПM-7038) }\end{array}$ & $11.5 \pm 0.3$ & $7.2 \pm 0.4$ & NA & $18.8 \pm 0.6$ & NA & NT & NT \\
\hline 8 & & \multirow{2}{*}{$\begin{array}{l}\text { clinical } \\
\text { strains }\end{array}$} & Staphylococcus aureus $(\mathrm{n}=4)$ & $9.1 \pm 0.6$ & $7.2 \pm 0.2$ & NA & $12.2 \pm 0.4$ & NA & NT & NT \\
\hline 9 & & & MRSA $(n=4)$ & NA & NA & NA & NA & NA & NT & NT \\
\hline 10 & \multirow[t]{4}{*}{ Fungi } & \multirow[t]{2}{*}{$\begin{array}{c}\text { reference } \\
\text { strains }\end{array}$} & $\begin{array}{l}\text { Candida. albicans } \\
\text { (ATCC 885-653) }\end{array}$ & $10.3 \pm 0.5$ & $8.0 \pm 0.2$ & NA & NA & $15.4 \pm 0.6$ & 250 & 500 \\
\hline 11 & & & $\begin{array}{l}\text { Candida albicans } \\
\text { (ATCC 668-853) }\end{array}$ & $10.2 \pm 0.3$ & $8.0 \pm 0.2$ & NA & NA & $16.2 \pm 0.2$ & NT & NT \\
\hline 12 & & \multirow{2}{*}{$\begin{array}{l}\text { clinical } \\
\text { strains }\end{array}$} & Candida dubliniensis $(\mathrm{n}=4)$ & $6.6 \pm 0.2$ & NA & NA & NA & NA & NT & NT \\
\hline 13 & & & Candida albicans $(\mathrm{n}=4)$ & $8.0 \pm 0.7$ & $7.0 \pm 0.3$ & NA & NA & $7.6 \pm 0.4$ & 500 & 1000 \\
\hline
\end{tabular}

NA: no activity; NT: Not Tested; diameter of zone of inhibition $(\mathrm{mm})$ including the disc diameter of $6 \mathrm{~mm}$; data are presented as mean \pm SD $(\mathrm{n}=3)$. 
After adjusting turbidity of each broth culiture of bacteria with saline (0.5 McFarland), inoculation of Mueller Hinton and Sabouraud agar plates was performed by using cotton swabs $(6 \mathrm{~mm}$ diameter and containing $0.2 \mu \mathrm{m}$ of extract).

\section{Results and discussion}

The first set of analyses examined the chromatogram of the extracts under study (Figure 1).

Figure 1 and Table 2 show the results obtained. In the result of the study, the quantitative content of 38 volatile compounds was established, 32 of which were identified (Figure 1 and Table 2).

Table 2. Identified compounds of Anemone nemorosa L. chloroform fraction

\begin{tabular}{|l|c|l|c|}
\hline № & $\begin{array}{c}\text { Retention } \\
\text { time }\end{array}$ & \multicolumn{1}{|c|}{ Substance } & $\begin{array}{c}\text { Content } \\
\%\end{array}$ \\
\hline 1 & 6.659 & Caprylic aldehyde & 0.17 \\
\hline 2 & 7.317 & Limonene & 0.52 \\
\hline 3 & 8.231 & 4-Ethyldacane & 0.41 \\
\hline 4 & 14.562 & 7-n-Tripropyldecan & 0.47 \\
\hline 5 & 14.791 & Icosane & 0.18 \\
\hline 6 & 15.134 & Pentadecane & 0.15 \\
\hline 7 & 15,691 & $\begin{array}{l}\text { 2,3,6-Trimethyl-4- } \\
\text { octene }\end{array}$ & 0.12 \\
\hline 8 & 18.020 & $\begin{array}{l}\text { 2-Methylpenta- } \\
\text { decane }\end{array}$ & 0.22 \\
\hline 9 & 19.249 & 2-Methyltricosane & 0.32 \\
\hline 10 & 20.050 & Heneicosane & 0.44 \\
\hline 11 & 20.593 & $\begin{array}{l}\text { 2,4-bis(1,1- } \\
\text { dibutyl)phenol }\end{array}$ & 0.60 \\
\hline 12 & 23.579 & Heptadecane & 0.19 \\
\hline
\end{tabular}

\begin{tabular}{|c|c|c|c|}
\hline 13 & 24,122 & Tetracosane & 0.21 \\
\hline 14 & 24.894 & Heneicosane & 0.52 \\
\hline 15 & 27.724 & $\begin{array}{l}\text { 11-(1-Ethylpropyl)- } \\
\text { Heneicosane }\end{array}$ & 0.24 \\
\hline 16 & 29,224 & Tetracosane & 0.36 \\
\hline 17 & 29.967 & Pentacosane & 0.32 \\
\hline 18 & 30.453 & Etyl palmitate & 1.23 \\
\hline 19 & 32.582 & Ethyl linoleate & 0.88 \\
\hline 20 & 32.711 & Dibutyl Sebacate & 6.11 \\
\hline 21 & 32.954 & Stearyl Alcohol & 0.77 \\
\hline 22 & 33.411 & $\begin{array}{l}\text { Fumaric acid 2,2- } \\
\text { dicloroethyl } \\
\text { tridecyl ester }\end{array}$ & 0.25 \\
\hline 23 & 33.726 & $\begin{array}{l}\text { Acetyltributyl } \\
\text { citrate }\end{array}$ & 31.21 \\
\hline 24 & 34.626 & $\begin{array}{l}\text { Oleamide } \\
\text { methylate }\end{array}$ & 0.55 \\
\hline 25 & 34.726 & Oleamide & 1.28 \\
\hline 26 & 35.712 & Dibutyl Sebacate & 0.33 \\
\hline 27 & 36.155 & Dioctyl Sebacate & 0.83 \\
\hline 28 & 36.612 & Heneicosane & 0.54 \\
\hline 29 & 38.170 & Decyl octyl adipate & 0.79 \\
\hline 30 & 38.699 & Oleamide & 1.26 \\
\hline 31 & 40.542 & Docosane & 0.39 \\
\hline 32 & 46.030 & $\begin{array}{l}\text { Pelargonic acid } \\
\text { tridecyl ester }\end{array}$ & 1.15 \\
\hline 33 & 46.173 & $\begin{array}{l}\text { 2,4-Difluoro- } \\
\text { benzoic acid } \\
\text { nonadecyl ester }\end{array}$ & 3.47 \\
\hline 34 & 48.145 & Rimuene & 2.81 \\
\hline 35 & 48.388 & $\begin{array}{l}\text { Pyridine-3- } \\
\text { carboxamide }\end{array}$ & 2.54 \\
\hline 36 & 48.545 & $\begin{array}{l}\text { 1,5-Dimethyl- } \\
\text { benzacridine }\end{array}$ & 0.78 \\
\hline 37 & 48.774 & Loxapine & 1.92 \\
\hline 38 & 48.916 & $\begin{array}{l}\text { Metoxyacetic acid } \\
\text { heptadecil ester }\end{array}$ & 1.19 \\
\hline
\end{tabular}




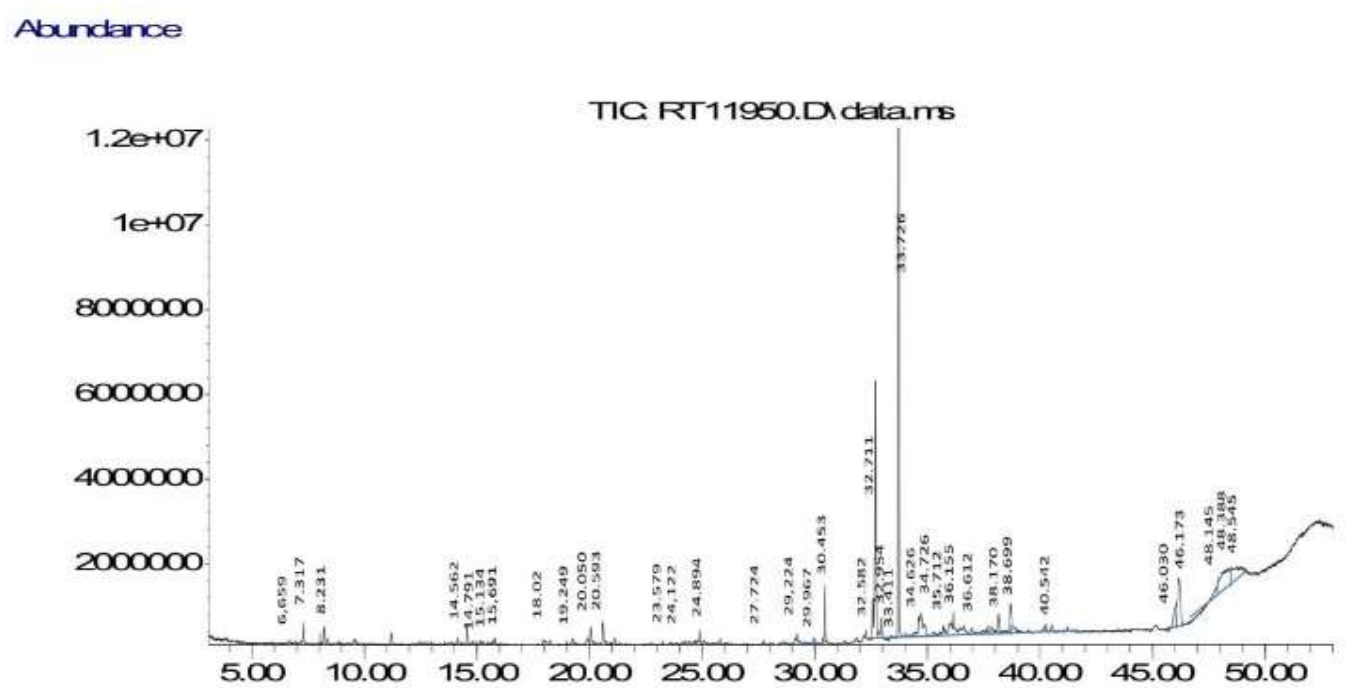

Figure 1. Chromatogram of volatile compounds of the Anemone nemorosa L. chloroform fraction

As it can be seen from these data, in the study of the component composition of the Anemone nemorosa chloroform fraction, 32 compounds were identified, they being paraffinic hydrocarbons, esters, fatty aldehydes and terpenes.

Further analysis showed that the dominant component in the sample was Acetyltributyl citrate $-31,21 \%$. Among others, there were Oleamide - 3,09\%, Loxapine 1,92\%. The identified esters were: Dibutyl sebacate - 6,44\%, 2,4-Difluorobenzoic acid nonadecyl ester - 3,47\%, Metoxyacetic acid heptadecil ester $-1,19 \%$, Pelargonic acid tridecyl ester $-1,15 \%$. The following alkanes were present: Heneicosane - 1,5\%, Tetracosane $0,53 \%$, Docosane - 0,39\%. Terpenes in the sample were presented by Monocyclic monoterpenes limonene $-0,52 \%$ and Diterpene rimuene $-2,81 \%$.

The results obtained of the study biological activity of Anemone nemorosa chloroform fraction suggest that the lipophilic extract under study has antimicrobial and antifungal activity against referece and clinical MDR strains Gramm-positive bacteria and fungi. The maximal antimicrobial action of the investigated extract was shown in relation to E. coli. When applying the method of serial dilutions, it was found that the maximum bactericidal effect of the tested extract was expressed relative to $E$. coli in dilution 1:4.

\section{Conclusions}

This study set out to analyse the composition of Anemone nemorosa chloroform fraction. The Anemone nemorosa lipophilic fraction was obtained using the method of exhaustive extraction with chloroform in the Soxhlet extractor. The yield was 6,93\%.

Using chromatography-mass spectrometry, the component composition of the volatile matter of the Anemone nemorosa chloroform fraction was obtained for the first time. 
38 substances were discovered, with 32 of them being identified.

This study has shown that the Anemone nemorosa lipophilic extraction has an antimicrobial action on reference and clinical MDR strains of both gram-positive, gramnegative microorganisms and Candida spp. The maximal antimicrobial action of the investigated extract was shown in relation to $E$. coli.

One of the more important findings to emerge from this study is that the significant content of biologically active substances in the Anemone nemorosa lipophilic volatile fraction indicates the prospect of their further study in order to create new medicinal products.

\section{References}

[1] Lukianchuk A, Khropot O, Konechnyi Y, Konechna R, Novikov V. Wood Anemone. Anemone nemorosa L. Analytical review. ScienceRise. Pharmaceutical Science 2017;3(7):34-38.

[2] Cumo CM. Encyclopedia of Cultivated Plants: From Acacia to Zinnia [3 Volumes]: From Acacia to Zinnia: ABC-CLIO, Santa Barbara, 1236 p.

[3] Botanical.com [homepage on the Internet]. Anemone (Wood); 1995-2017. Available from: http://Botanical.com/.

[4] Mondoni A, Probert R, Rossi G, Hay F, Bonomi C. Habitat-correlated seed germination behaviour in populations of wood anemone (Anemone nemorosa L.) from northern Italy. Seed Science Research 2008;18(4): 213-222.

[5] Bobadilla Fazzini RA, Skindersoe, ME, Bielecki P, Puchałka, J, Givskov M, Martins dos Santos VAP. Protoanemonin: a natural quorum sensing inhibitor that selectively activates iron starvation response. Environmental Microbiology 2013;15(1):111-120.
[6] Duan H, ZhangY, Xu J, Qiao J, Suo Z, $\mathrm{Hu} \mathrm{G}, \mathrm{Mu}$ X. Effect of anemonin on NO, ET-1 and ICAM1 production in ratin testinal microvascular endothelial cells. Journal of Ethnopharmacology 2005;104(3):362366.

[7] Huang YH, Lee TH, Chan KJ, Hsu FL, $\mathrm{Wu} \mathrm{YC}$, Lee $\mathrm{MH}$. Anemonin is a natural bioactive compound that can regulate tyrosinase-related proteins and mRNA in human melanocytes. Journal of Dermatological Science 2007;49(2):115-123.

[8] Jia D, Han B, Yang S, Zhao J. Anemonin alleviates nerve injury after cerebral ischemia and reperfusion $(\mathrm{i} / \mathrm{r})$ in rats by improving antioxidant activities and inhibiting apoptosis pathway. Journal of of molecular neuroscience 2014;53(2):271-279.

[9] Lee TH, Huang NK, Lai TC, Yang AT, Wang GJ. Anemonin, from Clematis crassifolia, potent and selective inducible nitric oxide synthase inhibitor. Journal of Ethnopharmacology 2008;116(3):518-527.

[10] Roth L, Daunderer M, Kormann K. Giftpflanzen-Pflanzengifte, Auflage 4: Nikol Verlag, Hamburg, 1090 p.

[11] Xiao K, Cao ST, Jiao LF, Lin FH, Wang $\mathrm{L}$, $\mathrm{Hu} \mathrm{CH}$. Anemonin improves intestinal barrier restoration and influences TGF-b1 and EGFR signaling pathways in LPS-challenged piglets. Innate immunity 20016;22(5):344-352.

[12] Hao DC, Gu H, Xiao P. Anemone medicinal plants: ethnopharmacology, phytochemistry and biology. Acta pharmaceutica Sinica B 2017;7(2):146-158.

[13] Martin ML, San Roman L, Dominguez A. In vitro activity of protoanemonin, an antifungal agent. Planta Medica 1990;56(1):66-69.

[14] Misra SB, Dixit SN. Antifungal principle of Ranunculus sceleratus. Economic Botany 1980;34(4): 362-367.

[15] Tsevegsüren N, Aitzetmfiller K. 7Linolenic Acid in Anemone spp. Lipids 1992;28(9):841846. 
[16] redbook-ua.org [homepage on the Internet]. Chervona knyha Ukrayiny; 2010-2017. Available from: http://redbook-ua.org/.

[17] Kozoriz O. Likarski roslyny Karpat. Dykorosli ta kulturni: Mystetska Liniya, Uzhgorod, 504 p.

[18] Hrodzinskyi M. Likarski roslyny: Entsyklopedychnyi dovidnyk: Vydavnytstvo "Ukrayinska Entsyklopediya” im. M.P. Bazhana, Kyiv, 544 p.

[19] Magiorakos AP, Srinivasan A, Carey RB, Carmeli Y, Falagas ME, Giske CG, Harbarth S, Hindler JF, Kahlmeter G, Olsson-Liljequist B, Paterson DL. Multidrug-resistant, extensively drug-resistant and pandrug-resistant bacteria: an international expert proposal for interim standard definitions for acquired resistance. Clinical microbiology and infection 2012;18(3):268-81. 